\title{
ANALISA KEAUSAN ELEKTRODA ELECTRICAL DISCHARGE MACHINING MENGGUNAKAN METODA RESPONSE SURFACE METHODOLOGY
}

\author{
Eko Yudo ${ }^{1}$, Husman ${ }^{2}$ \\ ${ }^{1}$ Jurusan Teknik Mesin - Politeknik Manufaktur Negeri Bangka Belitung \\ 2Jurusan Teknik Elektro dan Informatika - Politeknik Manufaktur Negeri Bangka Belitung \\ Kawasan Industri Airkantung Sungailiat-Bangka, 33211 \\ Telp.0717-93586, Fax.0717-93585, yudamessi2207@gmail.com
}

\begin{abstract}
The current electrical dish machine machining (EDM) machine in the field of manufacturing has developed along with conventional machines such as Lathes, Milling Machines, and Grinding Machines as the leading technology. EDM is known for its ability to make complex shapes on very hard metals. EDM machines are widely used in the manufacture of dies, cutting tools, and molds that cannot be done with the cutting process. Therefore the level of electrode wear in the EDM process must be as efficient as possible. The research was conducted to determine the exact EDM process parameter setting values. Variable parameters are current, on time, off time. To optimize the response of this study using the Response Surface Methodology (RSM) method. High electrode wear is obtained in testing with parameters used Ton $(300 \mu \mathrm{s}), T_{\text {off }}(15 \mu \mathrm{s})$ and Current $(20 \mathrm{~A})$, and the smallest wear value is obtained in the test with the parameters used $T_{\text {on }}(100 \mu \mathrm{s}), T_{\text {off }}(15 \mu \mathrm{s})$ and Current $(10 \mathrm{~A})$.
\end{abstract}

Keywords: EDM sinking, surface roughness (KP), Response Surface Methodology

\begin{abstract}
Abstrak
Mesin electrical dishcarge machining (EDM) dibidang manufaktur saat ini telah berkembang bersama dengan mesin konvensional seperti Mesin Bubut, Mesin Frais, dan Mesin Gerinda sebagai teknologi yang terdepan. EDM dikenal dalam hal kemampuannya untuk membuat bentuk kompleks pada logam-logam yang sangat keras. Mesin EDM banyak digunakan dalam pembuatan dies, perkakas potong, dan molds yang tidak bisa dikerjakan dengan proses penyayatan. Oleh karena itu tingkat keausan elektroda dalam proses EDM harus bisa seefisien mungkin. Peneltian dilakukan bertujuan untuk menentukan nilai setting parameter proses EDM yang tepat. Parameter yang divariasikan current, on time, off time. Untuk mengoptimalkan respon penelitian ini menggunakan metode Response Surface Methodology (RSM). Keausan elektroda yang tinggi didapat pada pengujian dengan parameter yang digunakan $T_{\text {on }}(300 \mu \mathrm{s}), T_{\text {off }}(15 \mu \mathrm{s})$ dan Current $(20 \mathrm{~A})$, dan nilai keausan yang terkecil didapat pada pengujian dengan parameter yang digunakan $T_{\text {on }}(100 \mu \mathrm{s}), T_{\text {off }}(15 \mu \mathrm{s})$ dan Current $(10 \mathrm{~A})$.
\end{abstract}

Kata kunci: EDM sinking, keausan Elektroda (KE), Response Surface Methodology

\section{PENDAHULUAN}

Pada tahun 1770 ilmuan Inggris bernama Joseph Priestly menemukan efek erosi dari percikan arus listrik. Kemudian penemuan itu dikembangkan oleh ilmuan Rusia bernama B. Larzarenko tahun 1943 yaitu dengan memanfaatkan percikan arus listrik untuk membuat proses yang terkontrol untuk permesinan secara elektrik pada bahan konduktif yang kemudian dikenal dengan proses EDM.

Proses Electrical Discharge Machining (EDM) adalah proses pengerjaan material benda kerja atau suatu produk akibat dari sejumlah loncatan bunga api listrik yang terjadi pada celah elektroda (alat potong) dengan benda kerja. Loncatan bunga api listrik tersebut terjadi secara tidak kontinyu melainkan secara periodik terhadap waktu, terjadi di antara elektroda dan benda kerja yang terendam dalam fluida dielektrikum pada tegangan listrik lebih besar dari 20 volt. Loncatan bungan api listrik menyebabkan pemusatan aliran elektron kecepatan tinggi dan menumbuk permukaan benda kerja. 
Dengan demikian besarnya kecepatan pengerjaan benda kerja sangat dipengaruhi oleh temperatur leleh dari benda kerja itu sendiri. Secara umum, prinsip kerja proses EDM sinking diilustrasikan pada Gambar.1 [1].

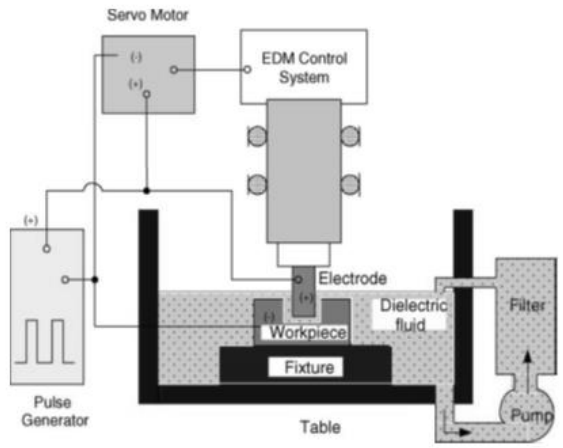

Gambar.1 Skema proses EDM sinking [1]

Proses pengikisan pada proses EDM sinking akan menyebabkan laju keausan elektroda (LKE), sedangkan proses erosi pada benda kerja merupakan proses pengerjaan benda kerja, produktivitas pengerjaan benda kerja di tunjukan oleh material removal rate (MRR) [2]. Proses pengikisan benda kerja dan elektroda tersebut tergantung pada parameter proses yang akan di variasikan: (i) Curren, (ii) Energy On Time, (iii) Energy Off Time. Tujuan dari penelitian ini adalah untuk mengatur parameter-parameter tersebut di atas, agar memungkinkan memperoleh keausan terjadi pada elektroda yang optimal. Proses terjadinya loncatan bunga api listrik di antara elektroda dan benda kerja tersebut adalah sebagai berikut:

a. Pada saat jarak terdekat elektroda dan benda kerja, terjadilah medan listrik yang kuat sehingga ion-ion positif $(\mathrm{M}+)$ dan elektron (e-), masing-masing mengalir pada kutup yang berlawanan.

b. Pada kondisi ini maka terbentuklah saluran ion yang bersifat kondusif, sehingga arus listrik dapat mengalir melalui saluran ion tersebut.

c. Tahanan listrik pada saluran ion menjadi rendah sehingga terjadi pelepasan energi listrik dalam waktu yang singkat berupa loncatan bunga api listrik. Gambar 2 menunjukan proses ionisasi yang menyebabkan loncatan bungan api listrik[3].

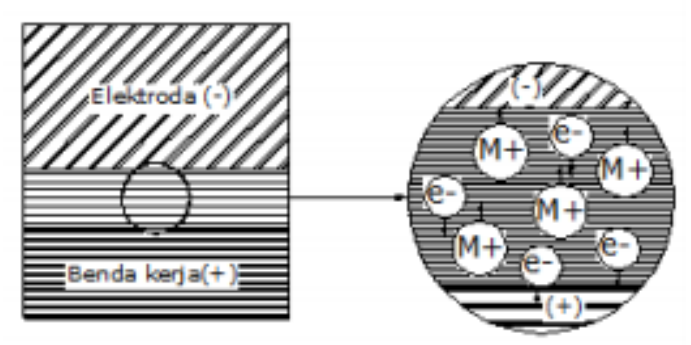

Gambar 2. Loncatan bunga api

Laju keausan elektroda (LKE) didefinisikan sebagai besarnya volume material yang dihasilkan per satuan waktu ( $\left.\mathrm{mm}^{2} / \mathrm{min}\right)$. LKE dapat diestimasi berdasarkan perubahan massa atau perubahan volume pada elektroda.

$$
\text { LKE }\left(\frac{\mathrm{mm}^{3}}{\min }\right)=\frac{\text { Volume material yang terbuang }\left(\mathrm{mm}^{3}\right)}{\text { Waktu pemesinan }(\text { Min })}
$$

Metode permukaan respon (response surface methodology) merupakan sekumpulan teknik matematika dan statistika yang berguna untuk menganalisis permasalahan dimana beberapa variabel independen mempengaruhi variabel respon dan tujuan akhirnya adalah untuk mengoptimalkan respon. Ide dasar metode ini adalah memanfaatkan desain eksperimen berbantuan statistika untuk mencari nilai optimal dari suatu respon. Metode ini pertama kali diajukan sejak tahun 1951 dan sampai saat ini telah banyak dimanfaatkan baik dalam dunia penelitian maupun aplikasi industri. Misalnya, dengan menyusun suatu model matematika, peneliti dapat mengetahui nilai variabel-variabel independen yang menyebabkan nilai variabel respon menjadi optimal. 


\section{METODE PENELITIAN}

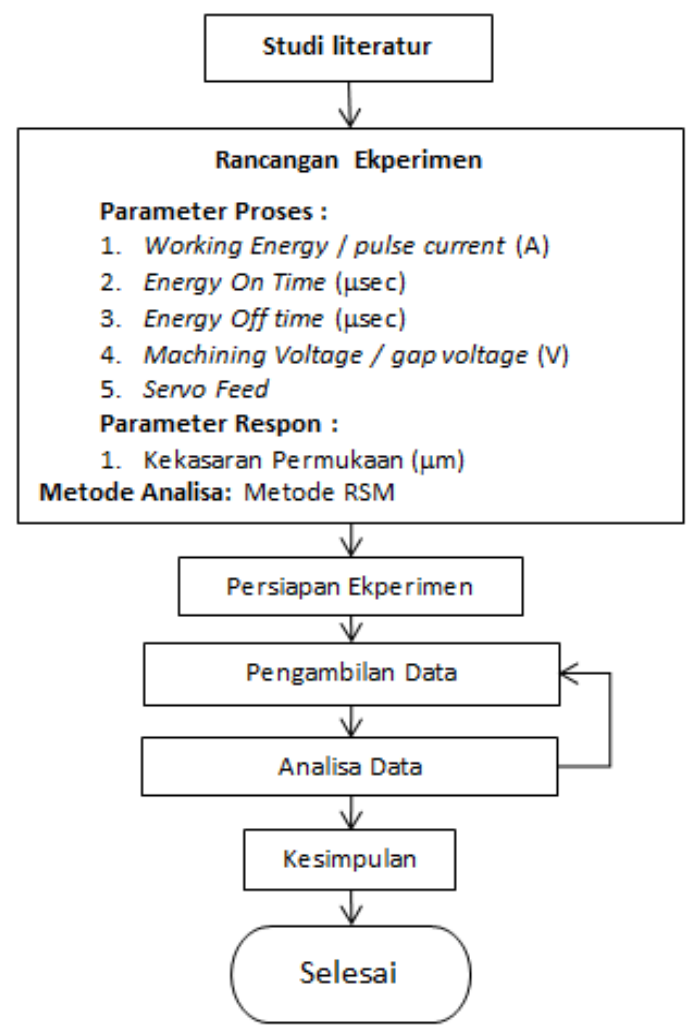

Gambar 3. Diagram penelitian

\subsection{Rancangan Penelitian}

Bahan yang digunakan pada penelitian adalah material baja AISI H13 dengan dimensi $\varnothing 25$ x 19 .

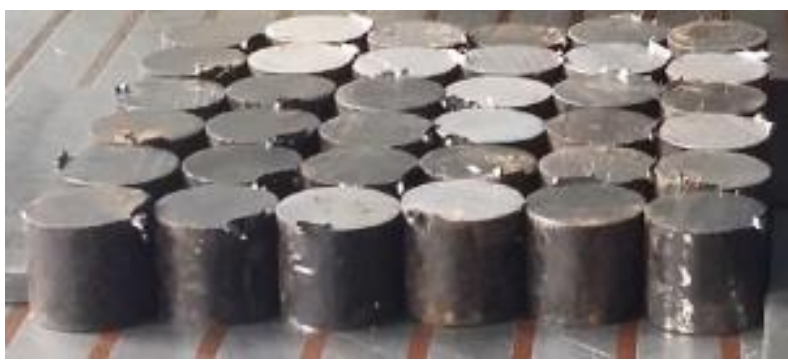

Gambar.4 Benda kerja

Material untuk elektroda atau pahat yang digunakan adalah tembaga. Dasar pemilihan elektroda tembaga ini adalah:

1. Memiliki sifat konduktor yang baik.

Dapat digunakan untuk semua jenis logam

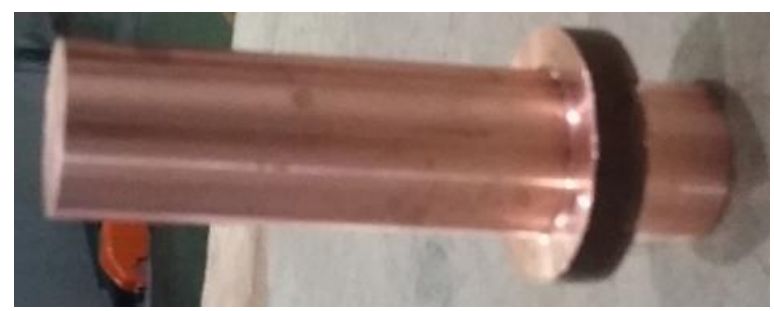

Gambar 5. Elektroda material tembaga 


\subsection{Alat Pengujian}

Untuk mempermudah dalam melakukan proses penelitian peralatan yang digunakan adaalah sebagai berikut:

\subsubsection{Mesin EDM}

Mesin EDM sinking yang digunakan adalah mesin Hitachi dengan Series H-DS02-S ditunjukkan pada Gambar 6.

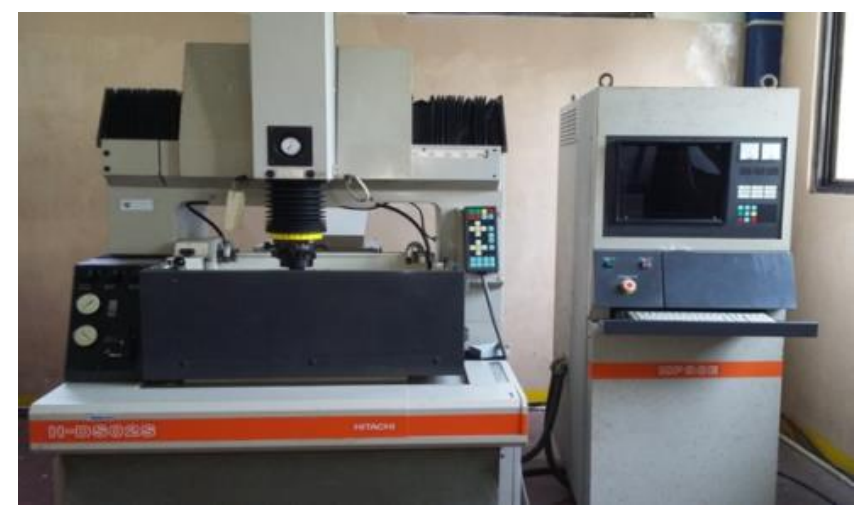

Gambar 6. Mesin EDM sinking H-DSO2-S

\subsubsection{Alat Ukur Surface Roughness Tester}

Alat ukur Surface Roughness Tester yang digunakan dalam penelitian ini adalah SURFTEST SJ-210 buatan Mitutoyo dengan kecermatan 0,01 $\mu \mathrm{m}$. Alat ini digunakan untuk mengukur berapa nilai kekasaran permukaan dari hasil pengikisan material menggunakan EDM sinking. Alat ukur tersebut dapat dilihat pada Gambar 7.

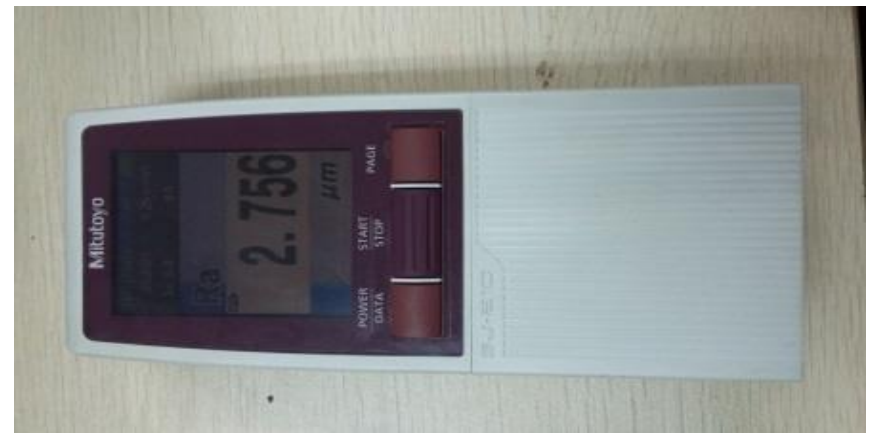

Gambar 7. Surface Roughness Teste SJ-210

\subsection{Parameter Penelitian}

\subsubsection{Parameter Proses}

Parameter proses adalah parameter yang dapat dikendalikan dan nilainya dapat ditentukan. Ada empat parameter proses yang digunakan pada eksperimen ini yaitu:

1. Arus (Current)

Arus listrik yang dihasilkan oleh mesin EDM ini antara $0-28 \mathrm{~A}$. Current yang digunakan adalah: 10A, 15, 20 dan 25A.

2. Energy On Time

On-time yang dihasilkan oleh mesin EDM ini antara $50-300 \mu \mathrm{s}$, namun yang dipilih adalah on time $100 \mu \mathrm{s}, 150,200$ dan $300 \mu \mathrm{s}$.

3. Energy Off Time

Mesin ini menghasilkan off-time antara $3 \sim 25 \mu \mathrm{s}$, namun pada penelitian ini dipilih dua level off-time yaitu 5, 10, 15 dan $20 \mu \mathrm{s}$. 


\subsubsection{Parameter Respon}

Parameter respon merupakan variabel yang besarnya tidak dapat ditentukan dan nilainya dipengaruhi oleh perlakuan yang diberikan, serta hasilnya diketahui setelah melaksanakan percobaan. Parameter respon yang digunakan pada penelitian ini adalah sebagai berikut:

1. Keausan Elektroda (KE)

\section{HASIL DAN PEMBAHASAN}

Pada pengolahan sample ini dilakukan secara acak dengan kombinasi variabel proses mengacu pada rancangan percobaan yang sesuai dengan perhitungan Desain of Experiment (DOE) dengan metode permukaan respon. Pengacakan ini dilakukan dengan menggunakan fasilitas randomisasi bilangan melalui bantuan perangkat lunak Design expert 9.0. Desain tersebut dikenal dengan Central Composite Design (CCD).

CCD yang digunakan meliputi 20 kali pengujian dan masing-masing titik variasi dengan pengulangan sebanyak 6 kali pada daerah pusatnya dengan menggunakan perangkat lunak Design Expert 10 dimana dari 3 parameter proses yang diambil yaitu energy on time $(\mu s)$, energy off time ( $\mu s)$ dan Ampere/current (A) didapat 20 sample percobaan yaitu :

Tabel 1. Hasil pengambilan data keausan elektroda

\begin{tabular}{|c|c|c|c|c|c|}
\hline \multirow[t]{2}{*}{ Std } & \multirow[t]{2}{*}{ Run } & Energy On Time & Energy Off Time & Current & $\begin{array}{l}\text { Keausan } \\
\text { elektroda }\end{array}$ \\
\hline & & $\mu \mathrm{s}$ & $\mu \mathrm{s}$ & Ampere & $\mu \mathrm{m}$ \\
\hline 1 & 19 & 100 & 5 & 10 & 0,041 \\
\hline 2 & 5 & 300 & 5 & 10 & 0,040 \\
\hline 3 & 10 & 100 & 15 & 10 & 0,011 \\
\hline 4 & 7 & 300 & 15 & 10 & 0,026 \\
\hline 5 & 1 & 100 & 5 & 20 & 0,272 \\
\hline 6 & 18 & 300 & 5 & 20 & 0,130 \\
\hline 7 & 11 & 100 & 15 & 20 & 0,070 \\
\hline 8 & 12 & 300 & 15 & 20 & 2,610 \\
\hline 9 & 4 & 31,82 & 10 & 15 & 1,169 \\
\hline 10 & 9 & 368,18 & 10 & 15 & 0,391 \\
\hline 11 & 16 & 200 & 1,59 & 15 & 0,086 \\
\hline 12 & 20 & 200 & 18,41 & 15 & 0,056 \\
\hline 13 & 6 & 200 & 10 & 6,59 & 0,033 \\
\hline 14 & 2 & 200 & 10 & 23,41 & 0,973 \\
\hline 15 & 17 & 200 & 10 & 15 & 0,712 \\
\hline 16 & 13 & 200 & 10 & 15 & 0,224 \\
\hline 17 & 8 & 200 & 10 & 15 & 0,197 \\
\hline 18 & 15 & 200 & 10 & 15 & 0,244 \\
\hline 19 & 14 & 200 & 10 & 15 & 0,185 \\
\hline 20 & 3 & 200 & 10 & 15 & 0,217 \\
\hline
\end{tabular}

Berdasarkan Tabel 1 dapat dijelaskan dimana keausan elektroda yang paling kecil terdapat pada energy on time $(100 \mu \mathrm{s})$ dan energy off time $(15 \mu \mathrm{s})$ dengan Ampere $(10 \mathrm{~A})$ dan keausan yang paling tinggi didapat pada energy on time (300 $\mu \mathrm{s})$ dan energy off time (15 $\mu \mathrm{s})$ dan Amper ( $20 \mathrm{~A})$. 
3.1. Hasil dan Pembahasan keausan Elektroda

Analisis varian (ANOVA) dari model linier yang telah didapat ditunjukkan pada Tabel 2.

Tabel 2. ANOVA for Response Surface Quadratic Model Keausan Elektroda

\begin{tabular}{|c|c|c|c|c|c|c|c|}
\hline \multirow{2}{*}{ Source } & \multicolumn{3}{|l|}{ Sum of } & \multirow{2}{*}{$\begin{array}{l}\text { Mean } \\
\text { Square }\end{array}$} & \multicolumn{3}{|l|}{$\mathrm{F}$} \\
\hline & Squares & DF & & & Value & Prob > F & \\
\hline Model & 15,81 & & 9 & 1,76 & 0,8 & 0,6267 & significant \\
\hline$A$ & 1,37 & & 1 & 1,37 & 0,62 & 0,4485 & \\
\hline B & 7,95 & & 1 & 7,95 & 3,62 & 0,0864 & \\
\hline C & 0,39 & & 1 & 0,39 & 0,18 & 0,6824 & \\
\hline $\mathrm{A} 2$ & 2,64 & & 1 & 2,64 & 1,2 & 0,2988 & \\
\hline B2 & 0,041 & & 1 & 0,041 & 0,018 & 0,8945 & \\
\hline $\mathrm{C} 2$ & 0,53 & & 1 & 0,53 & 0,24 & 0,6354 & \\
\hline$A B$ & $1,86 \mathrm{E}-03$ & & 1 & $1,86 \mathrm{E}-03$ & $8,47 \mathrm{E}-04$ & 0,9774 & \\
\hline$A C$ & 2,4 & & 1 & 2,4 & 1,09 & 0,3205 & \\
\hline$B C$ & 0,25 & & 1 & 0,25 & 0,12 & 0,7408 & \\
\hline Residual & 21,98 & & 10 & 2,2 & & & \\
\hline Lack of Fit & 5,5 & & 5 & 1,1 & 0,33 & 0,8733 & not significant \\
\hline Pure Error & 16,48 & & 5 & 3,3 & & & \\
\hline Cor Total & 37,79 & & 19 & & & & \\
\hline
\end{tabular}

Dari perhitungan ANOVA dapat dilihat bahwa Lack of Fit (LOF) dari model linier tidak signifikan dengan nilai Mean Square Erorr (MSE) yaitu 1,1. Model ini valid dan dapat digunakan untuk memprediksi nilai keausan elektroda.

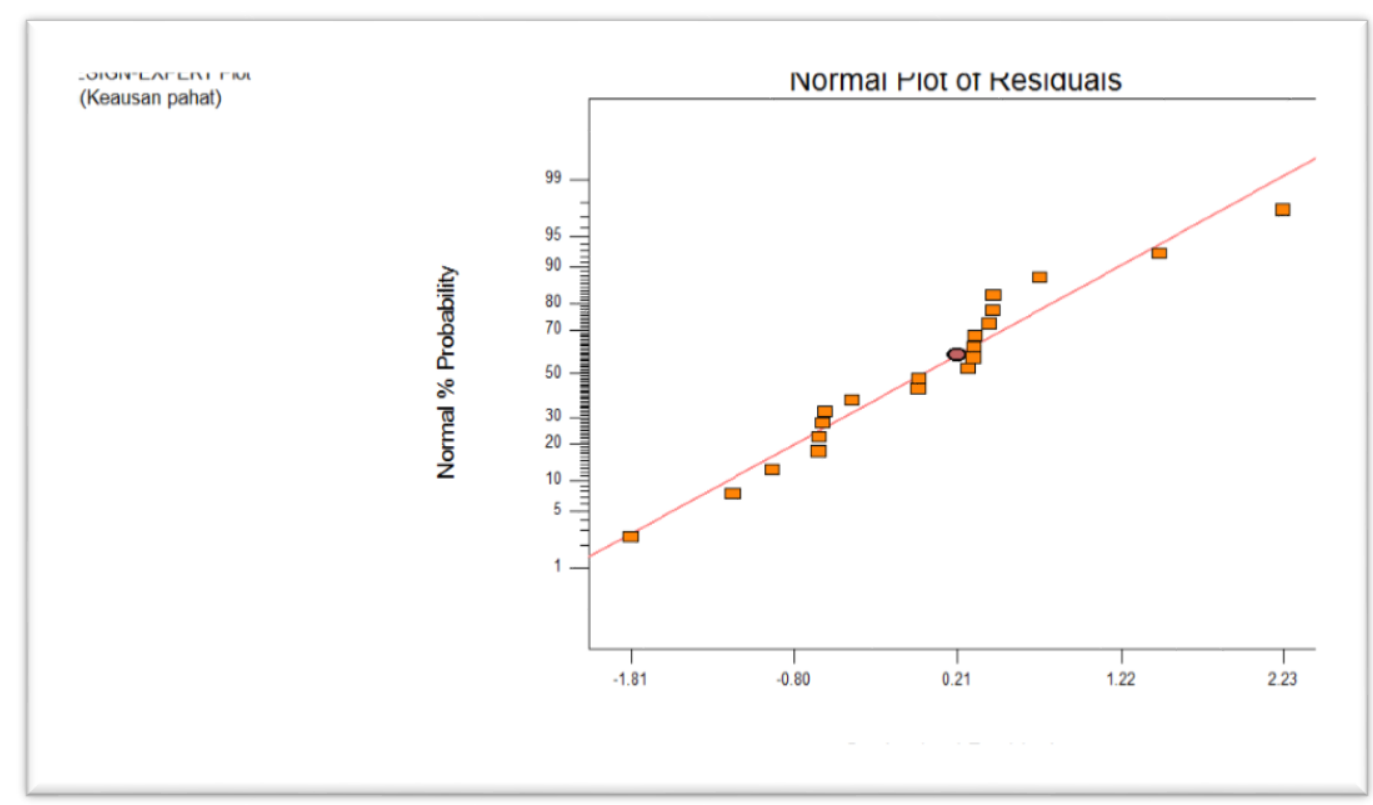

Gambar 8. Normal plot of residuals kekasaran permukaan 


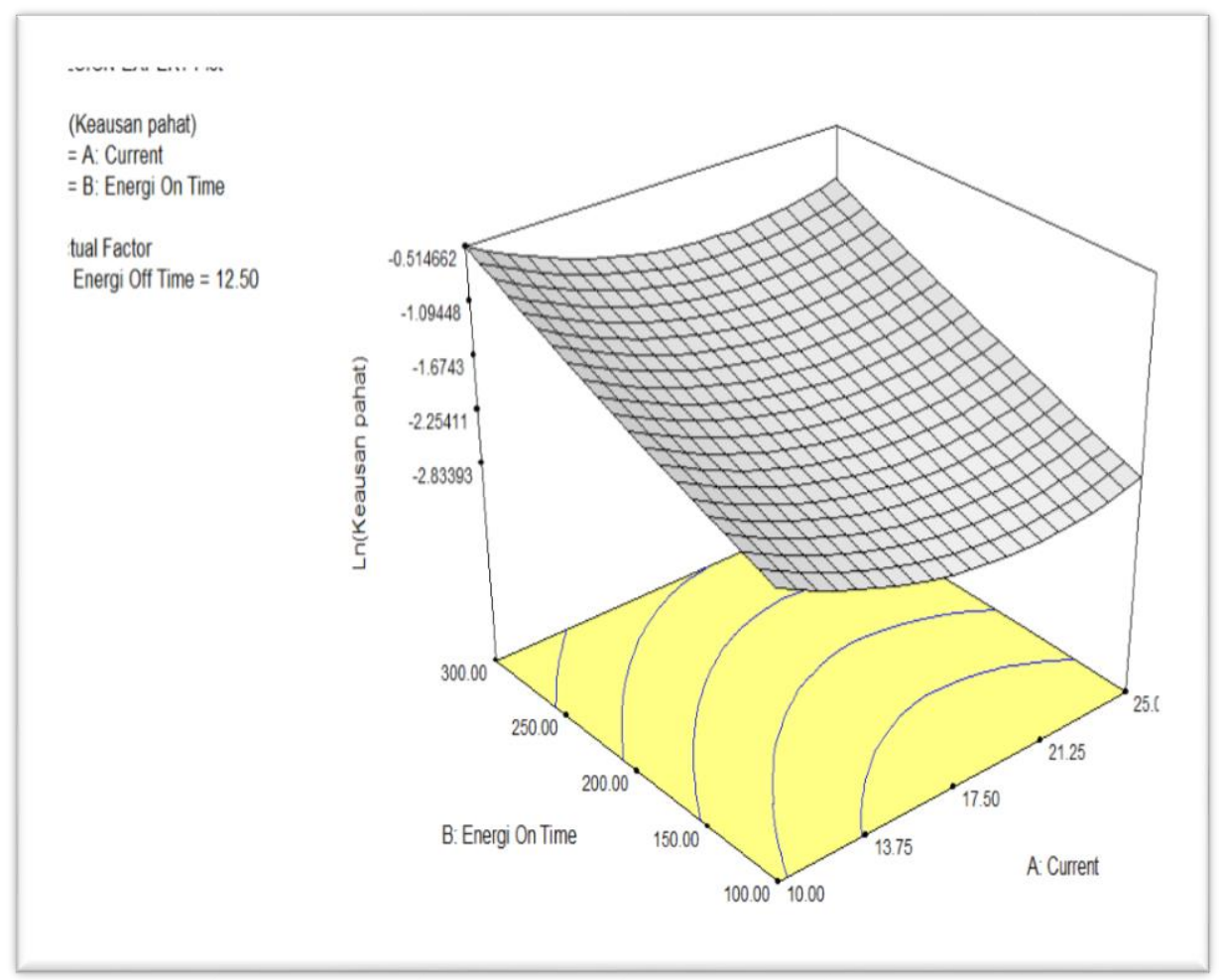

Gambar 9. Plot actual faktor Energy On Time keausan elektroda

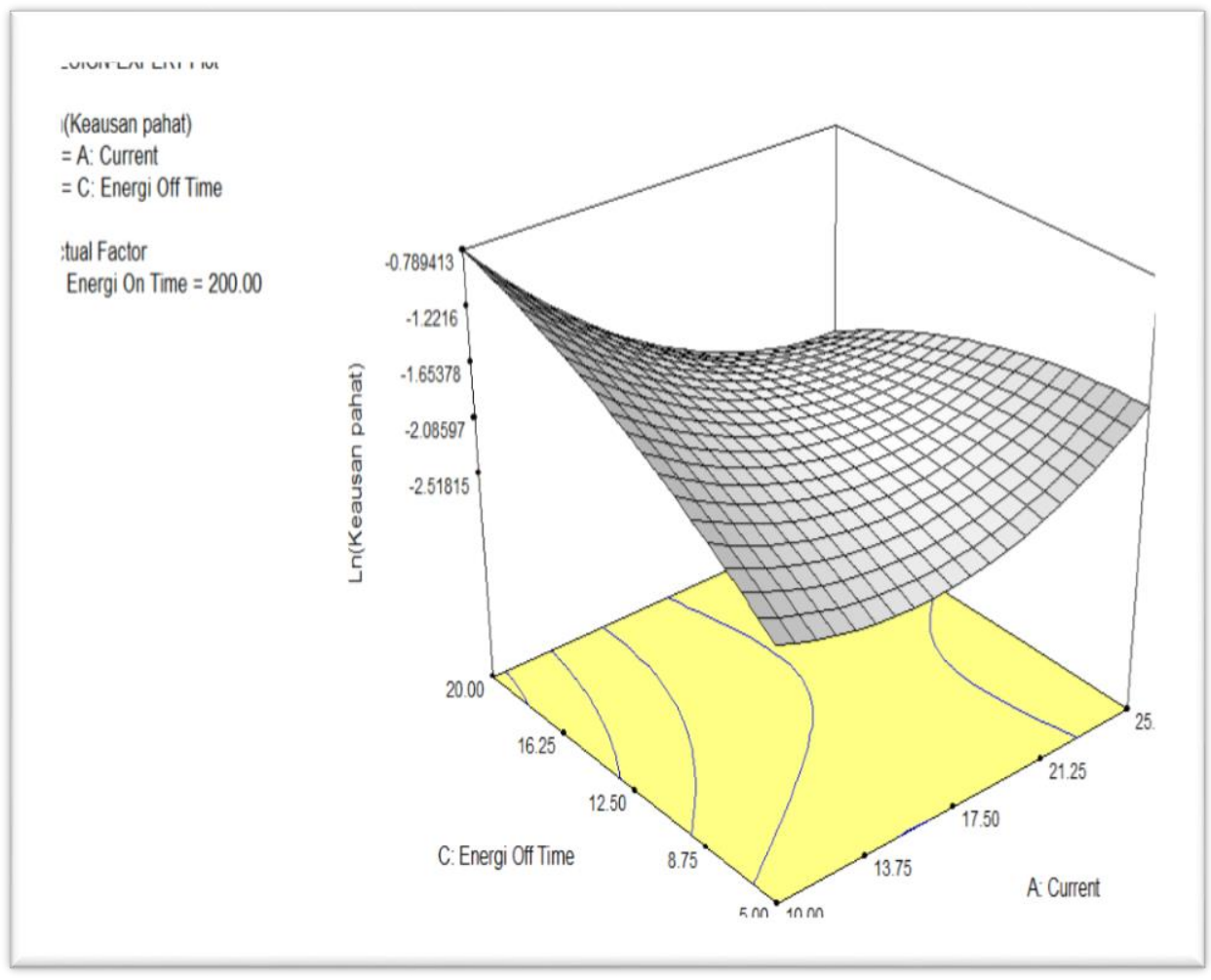

Gambar 10. Plot actual faktor Energy Off Time keausan elektroda 


\section{DESIGN-EXPERT Plot}

Ln(Kekasaran Permukaan)

$X=B$ : Energi On Time

$Y=C$ : Energi Off Time

Actual Factor

A: Current $=17.50$

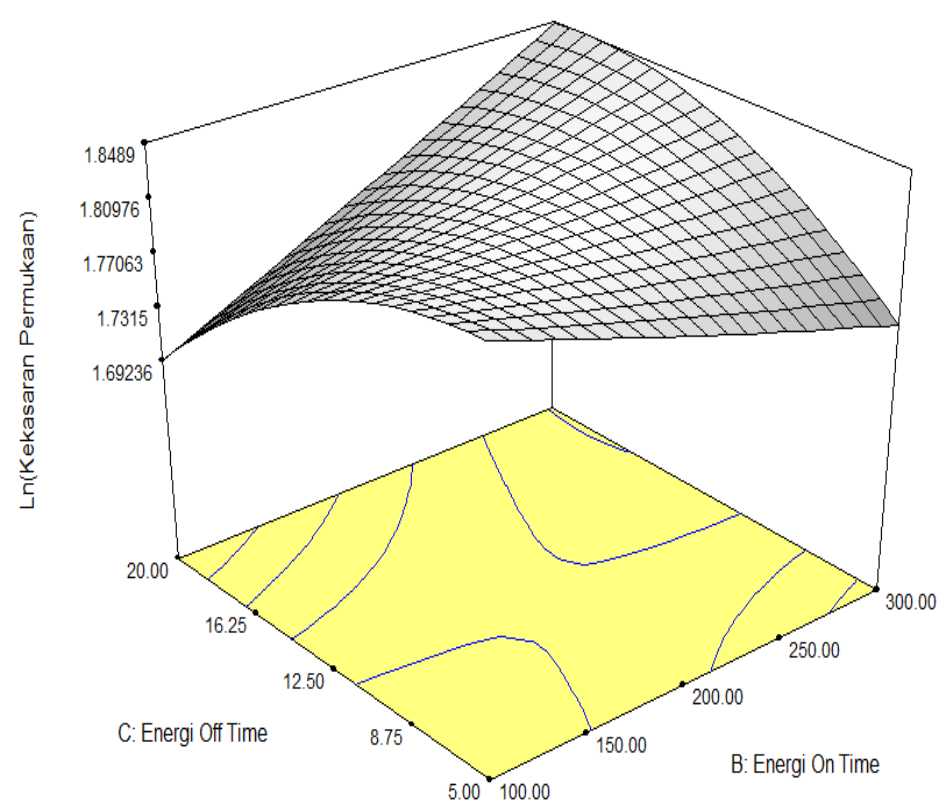

Gambar 11. Plot actual faktor Current Time keausan elektroda

\section{SIMPULAN}

Penelitian ini difokuskan pada Optimasi Parameter Pemotongan Untuk Pemotongan material baja AISI H13 di EDM singking dengan Aplikasi Metode RSM, dimana parameter kontrol adalah Energy On Time ( $T_{\text {on }}$ ), Energy Off Time ( $\mathrm{T}_{\text {off }}$ ) dan Ampere/Current $(\mathrm{A})$. Keausan elektroda dapat dilihat bahwa nilai keausan tertinggi diperoleh oleh pengujian ke-8 dengan parameter yang digunakan Ton (300 $\mu \mathrm{s})$, Toff (15 $\mu \mathrm{s})$ dan Ampere (20 A), dan nilai keausan yang terkecil diperoleh percobaan ke-3 dengan parameter yang digunakan Ton (100 $\mu \mathrm{s})$, Toff (15 $\mu \mathrm{s})$ dan Ampere (10 A) dengan demikian Ton sangat berpengaruh dalam bervariasinya nilai kekerasan spesimen.

\section{DAFTAR PUSTAKA}

[1] Lin, C.L., Lin, J.L. \& Ko, T.C., "Optimisation of the EDM Process Based on the Orthogonal Array with Fuzzy Logic and Grey Relational Analysis Method", journal of Advance Manufacturing Technology, pp.271-277, 2002.

[2] Gostimirovic Marin, dkk., "Influence of discharge energy on machining characteristics in EDM", Journal of Mechanical Science and Technology, 26(1)(2012)173 179, Springer, 2012.

[3] Londa Petrus, Lalel Bernard, "Analisa Keausan Elektroda pada Proses Electrical Discharge Machining", MeTrik polban, Jurnal Ilmiah Bidang Teknik Mesin, 2009.

[4] Hitachi MP30E, Machining technical Data Book, Kanagawa Japan: Hitachi Via Mechanics, Ltd.

[5] Krar, S. F.\& Check, A., Technology of Machine Tools fifth edit., Mc-Graw Hill International Editions, 1997.

[6] Rochim, T., Klasifikasi Proses, Gaya dan Daya Pemesinan. Lab.Teknik Produksi dan Metrologi Industri ITB, Bandung: Institut Teknologi Bandung, 2007.

[7] Myers, RH dan DC Montgomery. 1995.

[8] L Response Surface Methodology: Process and Product Optimization Using Designed Experiments, New York: John Wiley \& Sons, Inc.

[9] Nuryanti dan D.J. Salimy, "Metode Permukaan Respon dan Aplikasinya Pada Optimasi Eksperimen Kimia”, Dalam Risalah Lokakarya Komputasi dalam Sains dan Teknologi Nuklir: 6-7 (373-391), 2008.

[10] Montgomery, DC, Design and Analysis of Experiments 5th edition. New York: John Wiley \& Sons, Inc., 2001. 